\title{
THE CCNY AFFAIR
}

\author{
Louis Greenspan \\ Religious Studies / McMaster U. \\ Hamilton, oN, Canada L8S $4 \mathrm{KI}$ \\ GREENSPN@MCMASTER.CA
}

Thom Weidlich. Appointment Denied: the Inquisition of Bertrand Russell. Amherst, N.Y.: Prometheus Books, 2000. Pp. $233+8$ (illus.). us\$25.00.

When the Board of Higher Education of the City of New York voted, $W$ in February 1940, to offer Bertrand Russell a position as professor of philosophy at the City College of New York, they had no forewarning that their decision would touch off a cultural war as ferocious and divisive as any that we have experienced in recent decades. But unlike contemporary cultural wars, the CCNY dispute lasted only a few short months. It fizzled out because Russell's supporters were unwilling to commit themselves to an extended battle in the courts, and, Russell, needing an income, quietly accepted another position. The concerns that the cultural war raised were rapidly overshadowed by the military war that was taking place in Europe for, as the CCNY affair was ending, the Battle of Britain began. The controversy was never resurrected because it didn't seem to raise any issues of permanent importance. The charges that had been brought against Russell- - that he was sceptical concerning the philosophical validity of any absolute moral claims, that he believed that young men and women should be able to live together outside the framework of marriage, that adultery should not be taken so seriously as to be the most solemnly recognized basis for divorce, and, in his wilder moments, that homosexuality should not be a criminal offencewould hardly shake the moral foundations of any existing liberal democracy. In today's world of single mothers, sexual partnerships, Gay Pride and President Clinton's exegesis of what constitutes sexual relations, the storm over Russell's proposals seems as quaint as the Victorian debates over whether trains that were travelling over twelve miles an hour were breaking boundaries established by God. The CCNY affair is mainly remembered as a comedy. Its most celebrated document is attorney Joseph Goldstein's oft-repeated, colourful charge sheet which denounced Russell as "lecherous, libidinous, lustful, aphrodisiac, irreverent" and on and on--a document that Russell repeated with glee, boasting that his only predecessors were Apuleius and Othello. 
Thom Weidlich's Appointment Denied restores the episode to its proper place in Russell's life, in the history of academic freedom and, indeed, in the intellectual history of our times. He argues that the affair was not trivial and certainly not comic, and that it opened issues that remain unresolved.

On 26 February 1940, New York's Board of Higher Education approved the appointment of Bertrand Russell almost without discussion. It was one item in a full agenda of a liberal body that was meant to have an arm's length relationship to the government that had brought it into existence. Russell's appointment was so routine and without controversy that he was prepared to give up a position that he already held at UCLA (to the delight of the President of that institution).

On I March, Bishop Manning, spiritual leader of the city's Episcopalian community, sent a letter to the press in which he announced his outrage at the decision, and included direct quotations from Russell's writings that he felt certain would arouse any New Yorker concerned about the moral rectitude of the city. His letter created an immediate sensation. It called into existence a coalition consisting of the Hearst press and the various Catholic associations of the ciry. The latter were mobilized into a high state of militancy. Even police and associations of war veterans were addressed, with warnings that Russell's moral endorsement of adultery would produce an epidemic of jealous, murderous male violence. As the pressure mounted, Board members were thrown into confusion and dismay. Many demanded that the appointment be reconsidered.

On I8 March the Board met, again behind closed doors. But this time the corridors were invaded by over 200 observers. In a scene reminiscent of the crowds that harassed the Dreyfus jurors in Paris some decades earlier, some pounded on the door demanding to be heard-Weidlich adds, "throughout the evening Postal and Western Union telegraph boys kept coming up to the ninth floor, only to be told they couldn't go in the room" (p. 78). But in spite of the pandemonium without, the Board deliberated in calm for four hours and, in spite of some defections, upheld their original vote. The matter was closed.

So they thought. But Russell's opponents had already prepared themselves for this setback and, under a New York State law that allowed the courts to review the decisions of government institutions, brought a formal petition against Russell's appointment. The leading figures in this new phase were Mrs. Jean Kay (who, Weidlich tells us, seemed to come out of nowhere), who filed the petition on behalf of her daughter Gloria, and her attorney Joseph Goldstein; both were Jewish. Oddly the key figures, the Episcopalian Bishop and the Jewish prosecutors, gave the case some ecumenical dressing.

On 27 March the hearing was convened before Justice McGeehan, an
Irish Catholic Democrat, who, on 30 March, brought down his decision which ruled that the appointment was an insult to the people of New York and ordered that it be revoked. Russell and the Board had the option to appeal to a higher court, but the even Russell's supporters were beginning to demur. Russell himself threw in the towel and accepted an offer from Albert Barnes to join his institute in Philadelphia. The case, then, was never finally resolved on its merits. In the hearing lawyers for the Board believed that it would be resolved on technicalities. We don't know what would have happened in a higher court, nor after, had Russell's supporters prevailed. We do not know what further measures Russell's opponents would have taken, for the investigative committees into un-American activities, which would be so effective after the war, were coming into place.

Such is the sketch of the sequence of events that Weidlich sets out with clarity and dramatic skill. But beyond the narrative Weidlich gives a number of valuable accounts of the forces at work in New York-the nervousness about the war, the politics of Tammany Hall-in the broader intellectual context, including the political and intellectual appeal of Catholicism in the inter-war period, the state of academic freedom at the time and finally a chapter on Russell's views on sexual morality.

One aspect of the petition brought before the courts is curious-namely, the role of the Jews on the front line. Mrs. Kay and Attorney Goldstein came forward at a time when the Jewish community, for whom Russell was a longtime favourite, were either silent on the affair or actively supported Russell.

With regards to Mrs. Kay, Weidlich reveals that she had been offered a large sum of money (which she never received). This source of this revelation was her son, Sanford Kay, who came forward 6o years later. Why, then, did Attorney Joseph Goldstein prosecute the issue with greater zeal than any of Russell's other opponents? Here we can only speculate. Weidlich argues that the case made him an important public figure. Perhaps Goldstein was overcome by an opportunity for glory, but I would like to suggest another motive, a suggestion based on information that Weidlich provides.

Goldstein was an activist in the Jewish community, specializing in antidefamation issues. He once prosecuted a pro-Nazi German-language newspaper. He was thus keenly aware of antisemitism in the city and in the country. CCNY was a public university, with so large a Jewish student body it was nicknamed the Heder on the Hill. CCNY has been justly celebrated as one of the ladders in which an impoverished immigrant population was able to rise

I Nevertheless documents in the Russell Archives suggest that Russell thought he could teach at the Barnes Foundation and at CCNY if the appointment ever came through. Thus he pursued his lawsuit for breach of contract. (See RAI 8II.) 
to the centres of American intellectual life. For example, the socialist Irving Howe was educated at $\mathrm{CCNY}$, as was the neoconservative Irving Kristol. Graduates of CCNY have won eight Nobel prizes-more than any other institution in America. It seems reasonable to suppose that Goldstein feared that Russell's presence as the centrepiece of a Jewish institution would only exacerbate antisemitism. It would give ammunition to those who claimed that Bolshevism and free love were being brought to America by Jewish immigrants. This is merely a surmise but, I believe, a plausible one.

Despite the role of Bishop Manning and Joseph Goldstein, Weidlich treats the affair as one between American Catholicism, which championed the authority of revealed truth, and the secular educational system. It is impossible in a short paragraph to do justice to Weidlich's brief but illuminating chapters on Catholicism and on academic freedom. His account features an interplay of Catholic popular culture, that is, the growth and rising political clout of Irish Catholicism, and of Catholic high culture, in the growth and increasing prestige of Thomism. There is little doubt of the appeal of Thomism in the interwar period (and it seems to be growing again today). In his essays on English literature in the interwar period, Orwell, on many occasions, notes the attraction of Catholicism to the intelligentsia. Evelyn Waugh, Reginald Knox and Graham Greene, among others, became converts. Weidlich takes note of the intellectual sophistication of Thomism. It offered a critique of the modern world that matched that of the intellectual modernists. It emphasized revelation but also gave a sophisticated account of the role of reason. It thus offered a critique of modernity without falling into scepticism and nihilism. Russell criticized this Thomistic synthesis in his History of Western Philosophy. Weidlich notes that for all its sophistication the Church actively supported fascism.

For Weidlich the main lesson of this whole episode is that religious authority, i.e. authority which based itself on revelation, would not accept the separation of church and state in the field of higher education. Most philosophers in America supported Russell, even though many, such as John Dewey and Alfred North Whitehead, who bitterly disagreed with Russell philosophically, recognized that the autonomy of the academy was at issue. This was the issue that was put forward by Morris Cohen in his address to the students of CCNY. He told them, "There may be those who disapprove of our City Colleges becoming purely secular institutions. But ... how many of us wish to return to the condition of the middle ages...?" Thus it was a case of religion versus secularism. But Cohen also struck another theme when he said, "The citizens of New York city are facing a grave and momentous issue. Shall the higher education of our youth remain in the hands of competent and properly trained educators, or shall the appointment and removal of pro- fessors be controlled by popular clamour of the ignorant?" (p. 59)-meaning that it was also a case of the legitimate rule of qualified elites.

Weidlich's central theme, the contest between religious authority and the secular university, is, of course, crucial, but the theme that gives the whole affair an equally contemporary ring is the strategy by which the claims of revelation were wrapped in the rhetoric of democracy. Time and again Weidlich quotes religious authorities insisting that they were acting on behalf of the common man, the taxpayer. This democratic spin gives the affair the trappings of Socrates versus the Athenians.

First, Russell, like Socrates, was accused of corrupting youth. Secondly, he was accused of scepticism concerning the gods. Most important, however, is the way in which the opponents treated the conflict as one of the philosopher versus procedural democracy. Socrates was deemed an elitist because he was called the wisest man in Greece. Russell's case involved elitism because his appointment was decided upon behind closed doors by unelected members of the privileged classes. This is, of course, superficially true and raises the question of the role of the few in a democracy, especially with regards to the Arts and the Sciences.

In the Russell case the performance of the democratic court of Justice $\mathrm{McGeehan} \mathrm{was} \mathrm{comic} \mathrm{but} \mathrm{also} \mathrm{disturbing.} \mathrm{Ignoring} \mathrm{the} \mathrm{fact} \mathrm{that} \mathrm{American}$ universities were rescuing thousands of refugees from Nazi Germany, he emphasized that Russell was a foreigner, thereby pandering to the fears of the unemployed and precariously employed during the Depression. Secondlythe most farcical-he raised the question of whether Russell had taken a civil service exam for his appointment. Russell remarked later that only Whitehead would have been capable of examining him (p. 130). Finally, the judge delivered, as judges sometimes must, an account of the philosophical views of the accused, in this case Russell's views on marriage and sexuality. Weidlich does not do the judge a great favour by delivering a careful and fair-minded summary of the judge's views. Once set down with meticulous precision they are exposed as absurd and incompetent. The vaunted American genius for law was certainly not in evidence.

An irony in the whole affair is that Russell came under attack precisely at the time he was entering a period of conservatism. His writings in the ' 30 , especially Freedom and Organization, showed a growing distrust of Marxism and romantic radicalism and a greater appreciation for the traditions of Victorian liberalism. Shortly after the CCNY affair, while still at UCLA, Russell jettisoned his pacifism and for many years during and after the war became one of the most outspoken critics of Soviet Russia. His all-time best-seller, $A$ History of Western Philosophy, contains many warm statements about Christianity. After the war he was embraced as an establishment liberal, and received 
a handshake from the King. It is fitting, therefore, that Weidlich includes an account of the conservative emphasis regarding Russell's views on sexuality.

Weidlich argues that Russell's claim that reason cannot demonstrate an absolute standard for moral behaviour is not a recipe for moral anarchy. It is true that Russell frequently cites, with approval, Hume's maxim that reason is the slave of the passions, but, like Hume, he is not sanctioning a bacchanalian reverie for all individuals, as he knows as well as anyone that this would mean the destruction of society. Weidlich argues that in these statements Russell is addressing the desires of the social aggregate, not simply the individual, and arguing that the society that would give the maximum satisfaction of desire for all is the one that fosters those desires that do not put individuals in competition with one another. Ultimately Russell says that the good life is one inspired by love and guided by knowledge-hardly an ethos that threatens Christianity.

Weidlich also points out that, in spite of his own suspect record, Russell's views on sexuality were designed to help fortify modern marriage. He argued that the practice of making adultery the only legitimate cause for divorce, and all the arguments on behalf of severe sexual repression, were making sexuality too important in the life of the individual. Weidlich could have also noted that Russell's arguments against Christianity include Jesus' call for believers to abandon their father and their mother, as well as Paul's statement that it is better to marry than to burn, making marriage a second-best to celibacy, and thus they undermine the institution. Russell is one of the few who criticize Christianity as being contrary to family values.

What is the upshot of all this? Certainly Russell's experience in America convinced him that American society was vulnerable to waves of religious and political fanaticism that compelled it to betray its best ideals. Even when he became a militant cold warrior, he was wary of Americas commitment to political and intellectual freedom. After all, he had been offered a position in good faith, had accepted it in good faith and was then turned away by a popular clamour and threatened with loss of livelihood. So much for sanctity of contract. As for the Catholics, the Church has repented of its associations with fascism before and during the Second World War, but on the question of family ethics and sexuality it is officially as adamant as ever. Ironically in this most uncertain of all human ethical realms, the Church upholds the greatest certainty. This issue, it should be said, is also the one that has put the Church in great turmoil. As for the universities, the compact whereby society leaves them alone has grown stronger. Today, however, many look with nostaglia at the time that the attack on academic freedom came from the Right, or from the Church. Today the attack on academic freedom has come from within-first from the student left in the ' 60 s, which insisted that they should be the servants not of governments but of social movements. In recent years attempts have been made from within to limit freedom of expression by the introduction of legal codes against hostile racial expression and pornography. These codes have provoked the courts to intervene in universities on behalf of the Us First Amendment. The issues raised in the CCNY affair are still with us. Weidlich has shown that in its time the controversy was neither trivial nor comic; rather it was a dress rehearsal for the witch-hunts of Senator McCarthy. 